\title{
BLOOD COPPER AND ITS RELATIONSHIP TO THE GLOBULINS
}

\author{
BY \\ J. N. CUMINGS, H. J. GOODWIN, AND C. J. EARL \\ From the Department of Biochemical Research, Institute of Neurology, Queen Square, London
}

(RECEIVED FOR PUBlication AUGUST 13, 1954)

Holmberg and Laurell (1948) gave the name "caeruloplasmin" to a blue copper globulin complex which they had isolated from both pig and human blood (1947). It was obtained by ammonium sulphate precipitation and was found to be active as an oxidase against p-phenylenediamine. They considered it to be an $\alpha$ globulin with a molecular weight of about 150,000 . Other workers (Scheinberg and Gitlin, 1952 ; Bearn, 1953 ; Bearn and Kunkel, 1954a) agreed with these findings and also showed that caeruloplasmin was absent or very greatly reduced in hepatolenticular degeneration. Previously, however, Cohn (1948) had stated that copper in the human serum was combined with $\beta$ globulin, and in 1949 Thompson and Watson had shown that $25 \%$ of the blood copper was bound to $\gamma$ globulin, $55 \%$ to $\beta$ globulin, and only $10 \%$ to $\alpha$ globulin. Holmberg and Laurell (1951) obtained good correlation between the levels of copper and of oxidase activity in blood in normal subjects, but this fact seems at variance with the observation that, while the copper in the serum of patients with hepatolenticular degeneration may be reduced by half, yet the oxidase activity may be almost nil.

This paper records the results of further experiments designed to elucidate these problems.

\section{Material and Methods}

Blood was obtained from normal subjects and from patients suffering from various disorders, including five cases of hepatolenticular degeneration, with adequate safeguards to avoid contamination with extraneous copper.

The globulins were separated from the serum by precipitation with $15 \%, 19.6 \%$, and $26.8 \%$ anhydrous sodium sulphate saturation. Ether was used to facilitate separation, which was performed by centrifugation at 5,000 r.p.m. in a manner similar to that used by Thompson and Watson (1949). The following differences of technique were employed. The mixture of serum and salt was shaken by hand for five minutes in a water bath at $40^{\circ} \mathrm{C}$., and the centrifuge cups were also warmed to this temperature. Copper was estimated in both globulin precipitate and in the remaining solution as a check on the results. The method of estimation of the copper was a modification of the Eden and Green (1940) technique as used previously (Cumings, 1951), which involves the precipitation of the proteins by trichloracetic acid.

The oxidase activity of the serum and of each of the globulin fractions was estimated in a manner identical with that used by Bearn and Kunkel (1954a). The benzidine technique of Holmberg and Laurell (1951) was also employed.

\section{Results}

Thompson and Watson quote the reasons for assuming that the method they employed does give a reliable basis for the separation of the three globulins. Globulin fractions were accordingly submitted to electrophoresis on paper so that an estimate of the accuracy of the results obtained could be determined. Fig. 1 shows one example of such an electrophoretic experiment. It shows that $15 \%$ salt saturation yielded a precipitate containing only $\gamma$ globulin and that at $19.6 \%$ saturation as well as $\gamma$ and $\beta$ globulin there was a very slight trace of $\alpha_{2}$ globulin. However, the amount of $\alpha_{2}$ globulin was a very small fraction of the total $\alpha_{2}$ present in the serum when the curve obtained at $26.8 \%$ precipitation is inspected. This latter curve shows that all the globulins are precipitated at $26.8 \%$ saturation. In this experiment no albumin was found, but in one only of the other experiments a trace of albumin was detected. Apart from this experiment all other electrophoretic curves were practically identical with the one shown here. It would seem therefore reasonable to use this technique as a method for separating the globulin fractions in serum.

In the following tables only the percentages of the total copper bound to each globulin are recorded. It was found in every experiment that the amount of copper in the precipitate and in the remaining solution when added together gave a yield 
Electrophoretic Pattern of Globulin precipitated

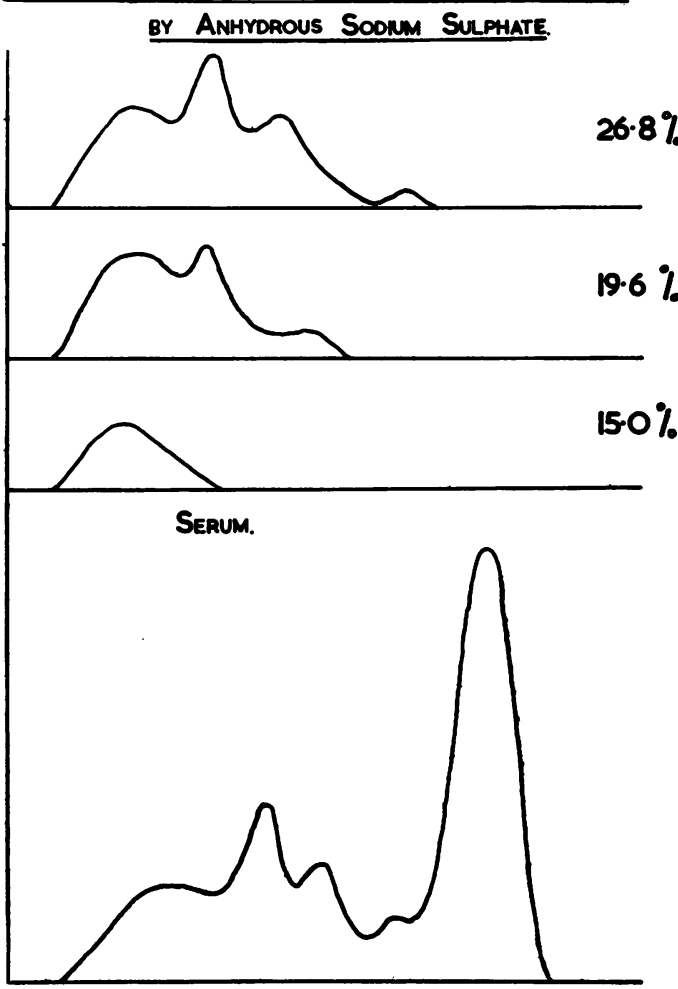

FIG. 1

of between $95 \%$ and $105 \%$ of the total serum copper.

Table I shows the results obtained in 10 normal subjects, from which it is seen that copper is bound in appreciable quantities by each globulin, and these findings are in agreement with those of Thompson and Watson, even though there is a greater variation from one specimen of blood to another in our experiments.

TABLE 1

GLOBULIN COPPER LEVELS IN NORMAL ADULT SUBJECTS

\begin{tabular}{|c|c|c|c|c|}
\hline \multirow{2}{*}{ Case } & \multirow{2}{*}{$\begin{array}{c}\text { Total Serum } \\
\text { Copper } \\
(\mu \mathrm{g} . / 100 \mathrm{ml} .)\end{array}$} & \multicolumn{3}{|c|}{$\begin{array}{c}\text { Percentage of Total Copper Recovered } \\
\text { from Globulin }\end{array}$} \\
\hline & & $\boldsymbol{\gamma}$ & $\boldsymbol{\beta}$ & $a$ \\
\hline $\begin{array}{r}1 \\
2 \\
3 \\
4 \\
5 \\
6 \\
7 \\
8 \\
9 \\
10\end{array}$ & $\begin{array}{c}102 \\
90 \\
115 \\
175 \\
122 \\
123 \\
150 \\
127 \\
180 \\
143\end{array}$ & $\begin{array}{r}33 \\
30 \\
22 \\
36 \\
21 \\
6 \\
22 \\
6 \\
9 \\
9\end{array}$ & $\begin{array}{l}33 \\
45 \\
34 \\
29 \\
46 \\
47 \\
48 \\
23 \\
52 \\
66\end{array}$ & $\begin{array}{l}18 \\
15 \\
39 \\
35 \\
29 \\
42 \\
25 \\
55 \\
35 \\
17\end{array}$ \\
\hline Average .. & 132.7 & 19.4 & $42 \cdot 3$ & 31.0 \\
\hline
\end{tabular}

Table II gives the results found in one patient with multilobular cirrhosis of the liver, in one patient with jaundice, the result of impacted gall $\frac{}{2}$ stones, and in four patients with involuntary move- 음 ments akin to those seen in hepatolenticular de- $\frac{\bar{\rho}}{\sigma}$ generation. These last four patients showed neither $\propto$ increased copper nor amino-acid excretion in the urine, and in no case was the diagnosis of hepatolenticular degeneration entertained. Included in $\circ$ the table are the protein contents of serum and of $\overrightarrow{\vec{\omega}}$ globulin fractions.

TABLE II

GLOBULIN COPPER LEVELS IN VARIOUS DISORDERS

\begin{tabular}{|c|c|c|c|c|}
\hline \multirow{2}{*}{ Case } & \multirow{2}{*}{$\begin{array}{c}\text { Total Serum } \\
\text { Copper } \\
\text { Level } \\
(\mu \mathrm{g} . / 100 \mathrm{ml} .)\end{array}$} & \multicolumn{3}{|c|}{$\begin{array}{l}\text { Percentage of Total Copper } \\
\text { Recovered from Globulin }\end{array}$} \\
\hline & & $\boldsymbol{\gamma}$ & $\boldsymbol{\beta}$ & $\boldsymbol{a}$ \\
\hline $\begin{array}{l}\text { Jaundice (gallstones) .. } \\
\text { Cirrhosis of liver } \\
\text { Abnormal movements } \\
\text { with syphilis } \\
\text { Abnormal movements } \\
\text { with multiple sclerosis }\end{array}$ & $\begin{array}{c}160(6.0) \\
193(6 \cdot 45) \\
97(6 \cdot 7) \\
113(7.5)\end{array}$ & $\begin{array}{l}15(1 \cdot 2) \\
32(1 \cdot 5) \\
12(0 \cdot 5) \\
19(0.6)\end{array}$ & $\begin{array}{l}66(1 \cdot 2) \\
32(1 \cdot 35) \\
48(1 \cdot 5) \\
60(1 \cdot 2)\end{array}$ & $\begin{array}{l}16(0.6) \\
19(1.05) \\
36(1 \cdot 2) \\
16(0.9)\end{array}$ \\
\hline $\begin{array}{l}\text { Athetosis } \because \text { Choreo-athetosis } \quad \text {. } \\
\text { C }\end{array}$ & $\begin{array}{l}103(6 \cdot 6) \\
137(7 \cdot 7)\end{array}$ & $\begin{array}{l}35(0.4) \\
26(0.7)\end{array}$ & $\begin{array}{l}41(0.8) \\
44(1.5)\end{array}$ & $\begin{array}{l}10(0.9) \\
14(0.9)\end{array}$ \\
\hline
\end{tabular}

( ) Indicates protein content in $\mathrm{g} .1100 \mathrm{ml}$.

The results are almost identical with those seen in Table $I$ as far as the copper is concerned, and it is further evident that the amount of globulin present bore no relationship to the amount of copper.

If all the above 16 results are added to the 12 obtained by Thompson and Watson the mean amounts of copper bound to $\gamma, \beta$, and $\alpha$ globulin are $23 \%, 48 \%$, and $20 \%$ respectively.

Five cases of hepatolenticular degeneration were also examined by this method, and the findings are 3 . recorded in Table III. All show striking differences $\dot{\delta}$ from the normal pattern, for all except one show an almost complete absence of copper on the $\alpha$ 의 globulin, while the fifth case showed an absence of copper on the $\beta$ globulin. All five cases had a low serum copper level, but none of the five showed

TABLE III

GLOBULIN COPPER LEVELS IN HEPATOLENTICULAR DEGENERATION

\begin{tabular}{|c|c|c|c|c|}
\hline \multirow{2}{*}{ Case } & \multirow{2}{*}{$\mid \begin{array}{c}\text { Total } \\
\text { Serum } \\
\text { Copper } \\
(\mu \mathrm{g} . / 100 \mathrm{ml} .)\end{array}$} & \multicolumn{3}{|c|}{$\begin{array}{l}\text { Percentage of Total Copper } \\
\text { Recovered from Globulin }\end{array}$} \\
\hline & & $\gamma$ & $\boldsymbol{\beta}$ & $a$ \\
\hline 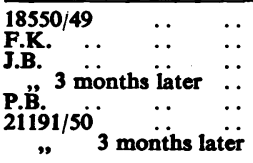 & $\begin{array}{l}66(6 \cdot 0) \\
57(5 \cdot 6) \\
64(6 \cdot 4) \\
53 \\
50(7 \cdot 4) \\
60(6 \cdot 1) \\
62\end{array}$ & \begin{tabular}{|l|}
$10(1.05)$ \\
$29(0.8)$ \\
$19(0.4)$ \\
24 \\
11 \\
$25(0.3)$ \\
15
\end{tabular} & $\begin{array}{l}58(0 \cdot 9) \\
11(1 \cdot 5) \\
25(1 \cdot 1) \\
26 \\
14 \\
8(0 \cdot 8) \\
4\end{array}$ & $\begin{array}{l}1(0.75) \\
2(0.3) \\
7(0.7) \\
4 \\
5 \\
26(0.8) \\
28\end{array}$ \\
\hline
\end{tabular}

() Indicates protein content in $\mathrm{g} . / 100 \mathrm{ml}$. 
any abnormal protein pattern. A further abnormal feature is that between. $30 \%$ and $60 \%$ of the serum copper appears firmly attached to the albumin, as was found by estimating the copper in the remaining solutions after precipitation of all the globulins with the $26.8 \%$ salt. A second examination was possible in two of the cases at some weeks' interval after the original estimations, and each pair of results are almost identical, as can be seen in the table.

It might be mentioned that the first and last cases are two of the four cases described previously (Cumings, 1951).

Table IV shows the results of measuring oxidase activity of three normal sera and of that of the globulin fractions from these same cases using the method of Bearn and Kunkel. The blood was obtained by therapeutic venesection, and this enabled us to obtain an adequate amount.

TABLE IV

OXIDASE ACTIVITY OF GLOBULIN FRACTIONS IN CONTROL SUBJECTS

\begin{tabular}{|c|c|c|c|c|c|c|c|c|c|}
\hline & \multicolumn{3}{|c|}{ Case 1} & \multicolumn{3}{|c|}{ Case 2} & \multicolumn{3}{|c|}{ Case 3} \\
\hline $\begin{array}{lcl}\text { Serum copper } & . . \\
\text { Oxidase } & \text { activity } & \text { of } \\
\text { serum } & . . & \ldots\end{array}$ & \multicolumn{3}{|c|}{$\begin{array}{l}127 \mu \mathrm{gg} / 100 \\
\mathrm{ml} . \\
158 \mu 10_{2} / \\
\mathrm{ml} . / \text { hour }\end{array}$} & \multicolumn{3}{|c|}{$\begin{array}{l}180 \mu \mathrm{g} . / 100 \\
\mathrm{ml} . \\
167 \mu 10_{2} / \\
\mathrm{ml} . / \text { hour }\end{array}$} & \multicolumn{3}{|c|}{$\begin{array}{c}143 \mu \mathrm{gg} / 100 \\
\mathrm{ml} . \\
119 \mu 10_{\mathrm{g}} / \\
\mathrm{ml} . / \text { hour }\end{array}$} \\
\hline \multirow{2}{*}{$\begin{array}{l}\text { Globulin fractions } \\
\% \text { Copper estimated } \\
\text { of total oxidase } \\
\text { activity .. } \quad . .\end{array}$} & $\gamma_{6}$ & $\begin{array}{c}\boldsymbol{\beta} \\
23\end{array}$ & $\begin{array}{c}a \\
55\end{array}$ & $\begin{array}{l}\gamma \\
9\end{array}$ & $\begin{array}{c}\beta \\
52\end{array}$ & $\begin{array}{c}a \\
35\end{array}$ & $\begin{array}{l}\gamma \\
9\end{array}$ & $\begin{array}{l}\beta \\
66\end{array}$ & $\begin{array}{l}a \\
17\end{array}$ \\
\hline & 23 & 77 & 0 & 22 & 65 & 13 & 9 & 91 & 0 \\
\hline
\end{tabular}

The percentage amounts of oxidase activity of the fractions is given, but the actual amounts of oxygen uptake of all three fractions approximated very closely to the total figure of the serum. It is seen that $\beta$ globulin shows the greatest activity, and that in the first and the third cases no activity was found in the $\alpha$ fractions. The electrophoretic charts shown in Fig. 1 were obtained from the serum and the globulin fractions actually used for oxidase activity estimations in Case 3, and, as the bulk of the $\alpha$ globulin is only present in the $26.8 \%$ salt saturation, this should have yielded oxidase activity had there been any in this fraction. A small amount only of oxidase activity was found in the $\gamma$ globulin fraction.

The examination of the sera from the five cases of hepatolenticular degeneration showed either no oxidase activity or only a very small amount, whether examined by the benzidine method or by the method using p-phenylenediamine, as can be seen in Table V. Further, in one of these cases no oxidase activity was found in any of the three globulin fractions.
TABLE V

OXIDASE ACTIVITY OF SERUM IN HEPATOLENTICULAR DEGENERATION

\begin{tabular}{|c|c|c|c|c|c|}
\hline & $18550 / 49$ & F.K. & J.B. & P.B. & $21191 / 50$ \\
\hline $\begin{array}{l}\text { Serum copper in } \\
\mu \mathrm{g} . / 100 \mathrm{ml} . \\
\text { Oxidase activity of } \\
\text { serum in } \mu 10_{2} / \mathrm{ml} . / \\
\text { hour }\end{array}$ & 66 & 57 & 64 & 50 & 60 \\
\hline & Control & Control & F.K. & J.B. & $21191 / 50$ \\
\hline $\begin{array}{cc}\text { Extinction } & \begin{array}{c}\text { readings } \\
\text { using benzidine tech- } \\
\text { nique }\end{array}\end{array}$ & 0.08 & 0.078 & 0 & 0.02 & 0.019 \\
\hline
\end{tabular}

Sera from two normal subjects has been mixed with sera from two cases of hepatolenticular degeneration, and oxidase activity determined in the mixtures. No inhibitory effect by the pathological sera was found in either case.

\section{Discussion}

The results obtained in normal sera are in agreement with those of Thompson and Watson, and show that there is a definite distribution of copper between all three globulins, but that the larger amount of copper is normally attached to $\beta$ globulin. Although it may perhaps be said that the methods used do not perfectly separate each of these three globulins, yet the bulk of evidence quoted by Thompson and Watson, taken with our electrophoretic evidence, does suggest that this method may reasonably be used. This view is further supported by the results of oxidase activity of the different globulins. Other workers have only used ammonium sulphate precipitation of all globulins to obtain the copper globulin complex. The electrophoretic studies of Bearn and Kunkel (1954b) cannot be used to refute this, as they were examining sera only some six or 12 hours after giving isotope copper, for Earl, Moulton, and Selverstone (1954) have shown conclusively that after giving $\mathrm{Cu}_{64}$ the albumin fraction takes up nearly $80 \%$ of this copper, and that even after 24 hours $20 \%$ or more is still attached to the albumin. In fact there is a transference of the $\mathrm{Cu}_{64}$ from albumin to globulin only after 24 hours, and therefore the studies of Bearn and Kunkel do not reflect the normal state of copper distribution.

Holmberg and Laurell suggest that there is a direct relationship between increased blood copper levels and increased oxidase activity, and by this they can only mean that all the copper in the serum possesses this enzymic activity. Does it mean then that each copper globulin complex has such activity? This would not seem to be true from the results shown in Table IV. Here the 
greatest oxidase activity was in the $\beta$ globulin fraction, and in two cases none was found in the $\alpha$ fraction even though some copper was found in this fraction in these cases. So far as we have found there has not been an absolutely good parallel between copper levels and oxidase activity in normal sera, but a very large number of such examinations are necessary.

Even greater difficulties emerge when the cases of hepatolenticular degeneration are considered. Serum copper levels are reduced in some cases, being half the normal, yet the oxidase activity is reduced even more. This has also been the experience of Bearn and Kunkel. Examination of the globulin fractions has shown an absence of $\alpha$ globulin copper in four cases, but the $\gamma$ and $\beta$ globulin copper complexes showed no oxidase activity. Further, one case differed from the others in twice showing no $\beta$ globulin copper. It must be admitted that at first it was felt that a mistake might have been made, even though it was known that this was virtually impossible. However, after passing a renal calculus this patient returned to hospital and a second examination was possible, and this verified the initial results. There appears to be no clinical distinction between this case and the others. Further, two of these patients had not been treated in any way before examination.

There is another point of importance that has to be considered. A large portion of the serum copper in these five cases was attached to the albumin $\checkmark$ fraction, and it is very probable that this is inactive in so far as oxidase activity is concerned. The copper remaining to the globulins may then be either too small in amount to exert oxidase activity, or it may be that a certain minimal amount is required before it can show such activity. It seems unlikely that there is an antagonist present to prevent such activity. The presence of copper combined with albumin as found in the above experiments is in accord with the results shown by Bearn and Kunkel (1954a), when they examined serum from cases of hepatolenticular degeneration electrophoretically on starch blocks. This may be of considerable importance, for it would seem that this albumin copper might be easily transferred to the tissues and it may be passed through the glomerulus with the urine. An attempt was made to see if it were possible that this copper was attached not to albumin but to an oligopeptide, but so far we have not been successful. Should this have been true it would have fitted in very well with the suggestions made by Uzman (1953) that the urinary copper is so linked.
Zimdahl, Hyman, and Cook (1953) showed that in hepatolenticular degeneration there is an abnormal uptake of copper from the intestinal tract, and should this be correct then this absorbed copper may be linked with albumin in the same way as $\mathrm{Cu}_{64}$ is in the experimental work of Earl et al. It may then be available to be deposited in the tissues or excreted in the urine before it has had time to be transferred from the albumin to the globulins, or because of some specific action which prevents such a transfer, or because of the absence of some enzyme which normally acts by transferring copper from albumin to globulin.

\section{Summary}

The amount of copper bound to $\gamma, \beta$, and $\alpha$ globulins has been estimated in normal subjects and in some pathological states, including five cases of hepatolenticular degeneration. It has been shown that $\beta$ globulin binds most copper, followed by the $\gamma$ and $\alpha$ fractions.

The cases of hepatolenticular degeneration differ in that in four cases no $\alpha$-binding copper was found, while in the remaining case no $\beta$ globulin copper was present.

Oxidase activity was found to be absent in all five cases of hepatolenticular degeneration, and also absent in each of the globulin fractions in one case.

Oxidase activity of the three globulin fractions was measured in three control subjects, and the greatest amount was found in $\beta$ globulin, while no activity at all was detected in the $\alpha$ globulin fraction in two cases.

These findings are briefly discussed in relation to the nature of hepatolenticular degeneration.

We desire to express our thanks to the many clinicians who have allowed us to examine their cases, and especially to Drs. S. Moeschlin and M. Meyer, of Zurich, Switzerland, who sent us blood from two cases of hepatolenticular degeneration. Our thanks are also due to the Research Advisory Committee of the Institute of Neurology, who defrayed the cost of apparatus.

\section{REFERENCES}

Bearn, A. G. (1953). Amer. J. Med., 15, 442.

and Kunkel, H. G. (1954a). J. clin. Invest., 33, 400

(1954b). Proc. Soc. exp. Biol., N.Y., 85, 44.

Cohn, E. J. (1948). Blood, 3, 471.

Cohn, E. J. (1948). Blood, 3, 471, 10.

Earl, C. J., Moulton, M. J., and Selverstone, B. (1954). Amer. J. Med., 17, 205.

Eden, A., and Green, H. H. (1940). Biochem. J., 34, 1202.

Holmberg, C. G., and Laurell, C.-B. (1947). Acta chem. scand., 1, 944. - (1948). Ibid., 2, 550 .

(1951). Scand. J. clin. Lab. Invest., 3, 103.

Scheinbers, I. H. and Gitlin, D. (1952). Science, 116, 484

Thompson R. H. S and Watson, D. (1949). Journal of Clinical Pathology, 2, 193 .

Uzman, L. L. (1953). Amer. J. med. Sci., 226, 645. 569. 